DOI: 10.47745/ERJOG.2020.04.02

\title{
FERENCZ JÁCINT
}

\section{Blockchain-rendszerü megoldások a munkaviszonyokban}

\section{Blockchain System Solutions in the Labour Relations}

\begin{abstract}
The essence of the blockchain technology lies in that via connected IT devices such a base of information is formed which simultaneously, with making a thousand copies, is able to register data of transactions, automated transactions, without any external supervision and the possibility of retrospective one-sided modification. Many believe that the system of blockchain (and the digital general ledger system forming its base) will bring about such a change into our lives which the Internet brought when it started to spread in the 1990s.

The most successful examples of blockchains so far are financial tools. The Court of the European Union has already ruled in judgement no. C264/14 that bitcoin virtual currency is considered to be a contractual money, it is a direct money between economic actors who accept it.

It is a perpetual dilemma of the law and legal regulations that lawmakers react to the events of everyday life slower than the speed at which economic actors find new solutions to various problems. Do new possibilities provided by blockchains surpass risks, or is it just like an Internet article warns: are hackers becoming the new lawyers? What can a corporate lawyer say to the previous question - can salary be asked for in bitcoin?

This presentation tries to answer the question of how much the blockchain system facilitates the conclusion of employment contracts or the fulfillment, the control, and the administration of employment relationships and whether the human element is indispensable in the operation of these systems.
\end{abstract}

Keywords: blockchain system, bitcoin, employment contract

Összefoglaló: A blockchain-technológia lényege, hogy összekapcsolt informatikai eszközök segítségével egy olyan információbázis jön létre, amely egyidejüleg akár több millió másolat készítésével, külső felügyelet nélkül képes tranzakciók adatainak nyilvántartására, automatizált ügyletkötésre a visszamenőleges egyoldalú módosítás lehetősége nélkül. Sokan úgy vélik, hogy a blokklánc-rendszer (illetve az alapját jelentő digitális főkönyvi rendszer) akkora változást fog hozni az életünkbe, mint amekkorát az internet elterjedése jelentett az 1990-es években.

A blokkláncok legsikeresebb példái ez idáig a pénzügyi eszközök. Az Európai Unió Bírósága a C264/14. sz. itéletében már megállapította, hogy a bitcoin virtuális deviza szerződéses fizetőeszköznek minősül, az azt elfogadó gazdasági szereplők közötti közvetlen fizetőeszköz.

A jog és a jogi szabályozás örök dilemmája, hogy a jogalkotó lassabban reagál a mindennapi élet eseményeire, mint amilyen gyorsan a gazdasági szereplők új és új megoldásokat találnak ki egy adott problémára. A blokkláncok által nyújtott új lehetőségek vajon felülmúlják-e a kockázatokat, vagy ahogyan egy internetes cikk fenyeget: a hackerek lesznek az új ügyvédek? Mit válaszolhat az előző bekezdésben felvetett kérdésre - kérhető-e a munkabér bitcoinban - a vállalati jogtanácsos? 


\section{ERDÉLYI JOGÉLET}

Jelen tanulmány arra keresi a választ, hogy vajon mennyire könnyíti meg a blockchain-rendszer a munkaszerződések megkötését, a munkaviszonyok teljesitését, ellenőrzését és adminisztrációját, illetve nélkülözhető-e a humán elem e rendszerek müködtetésében.

Kulcsszavak: blockchain, munkajog, munkaviszony létesítése, munkaszerződés, okosszerződés

Hacsak nem egy közel lakatlan szigeten élünk (a boldog információhiány állapotában), találkoznunk kellett a 21. század legkomolyabbnak tủnő vívmányával, az úgynevezett blockchain- vagy blokklánc-rendszerrel. Bár meggyőződésem, hogy a pontos működésével egyelőre kevesen vannak tisztában, a jelentősége tagadhatatlan. A technológia lényege, hogy összekapcsolt informatikai eszközök segítségével egy olyan információbázis jön létre, amely egyidejủleg akár több millió másolat készítésével, külső felügyelet nélkül képes tranzakciók adatainak nyilvántartására, automatizált ügyletkötésre a visszamenőleges egyoldalú módosítás lehetősége nélkül. ${ }^{1}$ Sokan úgy vélik, hogy a blokklánc-rendszer (illetve az alapját jelentő digitális főkönyvi rendszer) akkora változást fog hozni az életünkbe, mint amekkorát az internet elterjedése jelentett az 1990-es években.

Tudományos berkeken belül még óvatosan közelítünk a témához: az MTMT adatbázisa 2018. június 4-én mindössze 7 bejegyzést eredményezett a „blockchain” keresőszóra, és 4 bejegyzést a blokklánc kifejezésre, ami feltétlenül kevésnek tűnik ahhoz képest, hogy az amazon.co.uk oldal több mint 4000 könyvet ajánlott fel a témában angolul (blockchain szóra keresve a könyvek között). A nagy tudományos gyüjtőportálok közül a Social Science Reseach Network rendszerében 229 cikk foglalkozott már a címében is valamilyen módon a blokkláncokkal, döntő többségük 2015 utáni megjelenésủ munka. A jogi aspektusokkal ugyanakkor meglepően kevés szerző foglalkozik. 2015-ben Aaron Wright és Primavera de Filippi használták tudományos közleményben a „Lex Cryptographia" kifejezést, ${ }^{2}$ kifejtve, hogy a most tapasztalt jelenség a lex mercatoriához viszonyítva fontos hasonlóságokat mutat: a nemzetközi áru- és információcsere piaci szabályozása történik, nem hagyományos jogi struktúrákban, hanem önszabályozás keretében. Max Raskin egy érdekes példát említ a szabályozás körében: az ételautomatákba bedobott pénz - amennyiben az automata üzemszerüen működik - létrehozza az adásvételi ügyletet, és az eredmény pedig két elégedett üzletfél. Ez is egyfajta okosszerződés, és mindenki megelégedésére szolgál, amíg az automatikus müködés tárgyiasult eredménye egy üveg ásványvíz. És ha a gépből egy adag heroin is ugyanígy hozzáférhető? Be kell-e tiltani, kell-e szigorúan szabályozni az automatákat pusztán azért, mert illegális tevékenység folytatására is alkalmasak? ${ }^{3} \mathrm{~A}$ jogi munkák közül kiemelkedik Primavera De Filippi és Aaron Wright 2018-as munkája, amely a téma feldolgozásához alapműként

1 A blokklánc-technológiához kapcsolódó egyes fogalmakról ld. például: GLAVANITS Judit, KIRÁLY Péter Bálint: A blockchain-technológia alkalmazásának jogi előkérdései: a fogalmi keretek pontositásának szükségessége, Jog-Állam-Politika, 2018/3, 173-183.

2 Aaron Wright, Primavera De FiLIPPI: Decentralized Blockchain Technology and the Rise of Lex Cryptographia (March 10, 2015), https://ssrn.com/abstract=2580664 or http://dx.doi.org/10.2139/ ssrn.2580664

3 Max RASKIn: The Law and the Legality of Smart Contracts, Georgetown Law Technology Review, Vol. 1:2, 306. 


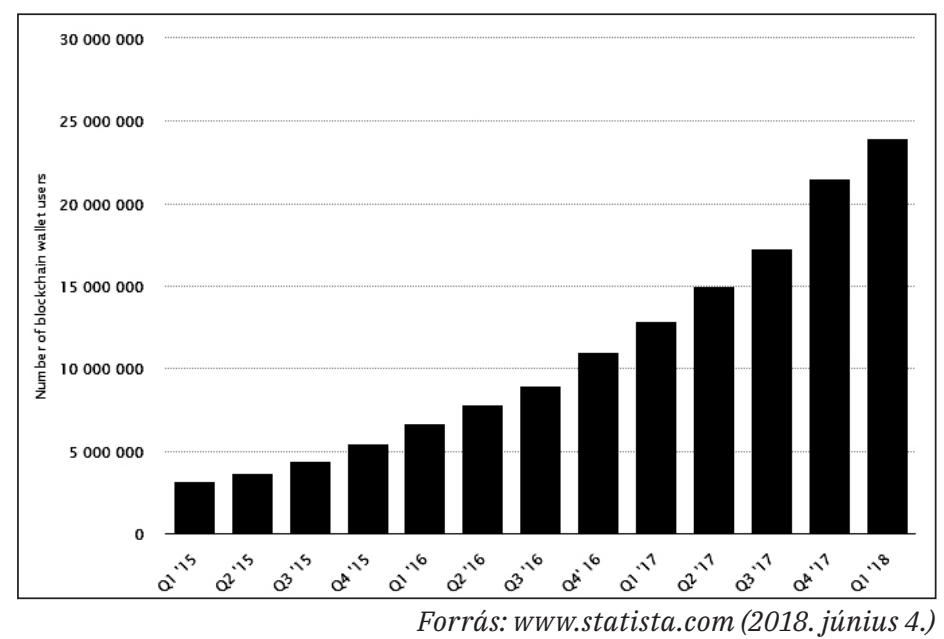

1. ábra. A blokklánc-pénztárcát használók számának alakulása

szolgál jogászok számára. ${ }^{4}$ A szerzők széles körben térképezik fel a blokkláncokban rejlő szabályozási kihívásokat, ugyanakkor felhívják a figyelmet az alkalmazhatóság széles skálájára is.

A blokkláncok legsikeresebb példái ez idáig a pénzügyi eszközök. Az Európai Unió Bírósága a C-264/14. sz. ítéletében már megállapította, hogy a bitcoin ${ }^{5}$ virtuális deviza szerződéses fizetőeszköznek minősül, az azt elfogadó gazdasági szereplők közötti közvetlen fizetőeszköz. Hazánkban az MNB 2014. február 19-én sajtóközleményt adott ki, amelyben kifejezetten felhívja a fogyasztók figyelmét a virtuális fizetőeszközökben rejlő veszélyekre. ${ }^{6}$ Pfeffer Zsolt szintén kiemeli (már 2017-ben), hogy nem hagyható figyelmen kívül a jogi bizonytalanság, hiszen a Bitcoin megkönnyíti az adóelkerülést, a pénzmosást és az illegális kereskedelmet (például drogügyletek lebonyolítását), így a vele szemben kilátásba helyezett kormányzati fellépések is kockázatossá teszik a felhasználását.? A fentiek ellenére a virtuális fizetőeszközöket használók száma folyamatosan növekszik. A Cambridge Center for Alternative Finance kutatási jelentése alapján azon gazdasági társaságok, akik maguk is használnak blokklánc-alapú pénztárcát, 69 százalékban

\footnotetext{
4 Primavera De FILIPI, Aaron WRIGHT: Blockchain and the Law. The Rule of Code, Harvard University Press, London, 2018, 74.

5 A bitcoin egy nyílt forráskódú digitális fizetőeszköz, amelyet 2009. január 3-án egy ismeretlen (internetes nevén Satoshi NАкАмото) bocsátott ki, közvetlenül a 2008-as amerikai bankválság kirobbanása után. Az elnevezés vonatkozik a fizetőeszközt kezelő nyílt forráskódú szoftverre, és az azzal létrehozott elosztott hálózatra is.

6 MNB: Az MNB kockázatosnak tartja a fizetésre használható virtuális eszközöket, például a bitcoint. Elérhetőség: http://www.mnb.hu/sajtoszoba/sajtokozlemenyek/2014-evisajtokozlemenyek/az-mnb-kockazatosnak-tartja-a-fizetesre-hasznalhato-virtualis-eszkozoketpeldaul-a-bitcoint (letöltés ideje: 2018. 04. 04.)

7 Pfeffer Zsolt: A fizetésre használható virtuális eszközök, Kodifikáció és Közigazgatás, 2017, 20.
} 
kis- vagy mikrovállalkozások, és főként az USA-ban és Európában rendelkeznek székhellyel. ${ }^{8}$ Nemsokára eljöhet az az idő, amikor a munkavállalók vagy érdekképviseleteik felvetik azt a kérdést, hogy a munkabért kaphatják-e kriptovalutában. ${ }^{9}$

A jog és a jogi szabályozás örök dilemmája, hogy a jogalkotó lassabban reagál a mindennapi élet eseményeire, ${ }^{10}$ mint amilyen gyorsan a gazdasági szereplők új és új megoldásokat találnak ki egy adott problémára. ${ }^{11} \mathrm{~A}$ blokkláncok által nyújtott új lehetőségek vajon felülmúlják-e a kockázatokat, vagy ahogyan egy internetes cikk fenyeget: a hackerek lesznek az új ügyvédek ${ }^{12}$ Mit válaszolhat az előző bekezdésben feltett kérdésre - kérhető-e a munkabér bitcoinban - a vállalati jogtanácsos? A kérdés felvetése nem lenne újszerü, hiszen 2017 decemberében egy japán vállalat már felajánlotta dolgozóinak, hogy 2018 márciusától fizetésük egy részét kérhetik bitcoinban. ${ }^{13}$ Ugyanakkor az Egyesült Államokban több szerző is felhívta a figyelmet arra, hogy (a kézirat lezárásakor) ennek az USA-ban nincsen meg a jogi lehetősége. ${ }^{14}$

A kérdés megválaszolásához nemcsak munkajogi, hanem pénzügyi jogi aspektusokat is figyelembe kell venni, így a bitcoin (vagy bármely más virtuális fizetőeszköz, más néven kriptovaluta) konvertibilitását, állami elfogadását. ${ }^{15}$ Ezen egyéb aspektusokkal a következőkben csak érintőlegesen foglalkozom, amennyiben az befolyásolja a munkajogi megítélését, vagy egyes kérdések eldöntésében segítséget nyújt.

\section{Az okosszerzödések és a digitális fökönyvi technológia}

A blokklánccal egy újfajta társadalmi kontrollviszony alapvető infrastrukturális eleme született meg. ${ }^{16} \mathrm{Az}$ okosszerződések (smart contracts) alatt egy olyan blokkláncra

8 Garrick Hileman, Michel Rauch: Global Cryptocurrency Benchmarking Study. Cambridge Center for Alternative Finance, University of Cambridge, Judge Business School, 2017, 48-50.

9 E körben érdekes kérdés lehet a munkajogi kártérítést illetően az, hogy a munkáltató kártérítési felelőssége esetén van-e mód arra, hogy a kriptovalutában rendszeresen elért vagyoni juttatást - mint lehetséges vagyoni kárt - figyelembe vegyük. E körben látunk némi hasonlóságot a jogsértő módon nem adózó, ún. „fekete jövedelem” figyelembe vehetőségére vonatkozó gyakorlattal. A kérdésről lásd bővebben: TRENYISÁN Máté: A munkáltató kártéritési felelőssége a magánmunkajogban (kismonográfia), Nemzeti Közszolgálati Egyetem, Budapest, 2018, 86.

10 G. KARÁCSONY Gergely: Okoseszközök - okos jog?, Ludovika Egyetemi Kiadó, Budapest, 2020, 75-77.

11 G. KARÁCsONy Gergely: A mesterséges intelligenciák szabályozásának közjogi kérdései = A gazdasági jogalkotás aktuális kérdései, szerk. Glavanits Judit, Dialóg Campus Kiadó, Budapest, 2019, 56.

12 https://www.bitcoinbazis.hu/okosszerzodes-ugyved-vagy-hacker/ (letöltés ideje: 2020.11. 03.)

13 https://www.inc.com/eric-mack/meet-publicly-traded-company-paying-employees-inbitcoin.html (letöltés ideje: 2020. 11.03.)

14 Lásd például: Kayla Matriews: Why Employers Can't Pay You in Cryptocurrency. https:// cointelegraph.com/news/why-employers-cant-pay-you-in-cryptocurrency (letöltés ideje: 2018. július 13.)

15 A blokkláncon alapuló technológiák állami felhasználásának lehetőségeiről ld. még: GLAvanits Judit: Sustainable Public Spending Through Blockchain, European Journal of Sustainable Developement, 2020/4, 317-327.

16 Z. Karvalics László, NAGy Gábor Dániel: Prokrusztész nélküli világ? Blokklánc és társadalmi makroevolúció, Információs Társadalom, XVII. évf. (2017) 3. szám, 7-38. 
épülő alkalmazást, algoritmust értünk, amely bizonyos feltételek teljesülése esetén automatikusan végrehajt egy következményt. Az okosszerződés egy tranzakcióhoz kapcsolódóan leírja a megállapodást, az egyes felek tennivalóit, jogait és kötelezettségeit, valamint annak végrehajtási részleteit. Ezt értelmezhetjük úgy, mint a hagyományos szerződési feltételeket, azzal a különbséggel, hogy nem a megszokott szabad szöveges, jogászi megfogalmazásban írt és értelmezett, hanem digitálisan kódolt utasítások formájában megjelenő rendszer. ${ }^{17}$

Az okosszerződések nyilvántartása a blokklánc-rendszerben, vagy általánosabban a digitális fökönyvi rendszerben történik. A DLT (digital ledger technology) egy olyan hálózat, amelyben az adatok a hálózat tagjai között szinkronizált módon megosztásra kerülnek. A rendszer működéséhez kapcsolatot szükséges létesíteni és fenntartani a hálózat minden tagja között, továbbá létre kell hozni egy konszenzuson alapuló algoritmust, amely alapján a hálózat tagjai részt vesznek a hálózaton keresztül folytatott tevékenységekben. Az elosztott főkönyvi rendszer lehet egyaránt privát vagy publikus, tehát nem kizárt, hogy például egy vállalat létrehozza a saját belső DLT alapú vállalatirányítási rendszerét. Innentől pedig már csak egy ugrás a munkavállalók, illetve a foglalkoztatási jogviszony egészének bevonása a hálózatba. Ehhez szükséges megvizsgálni, hogy a munkaszerződések, a munkaviszonyok digitalizálhatóak-e, kódolhatóak-e egyáltalán?

Megjegyzendő, hogy az automatizált, elektronikus szerződéskötésnek és a digitalizált munkaügyi folyamatoknak mára a magyarországi gyakorlata is kialakulóban van. Bár számosságát és elterjedtségét vélelmezni nem lehet, de egy, a közelmúltban megjelent, nagyvállalati tapasztalatokra építő beszámoló e folyamatok tényleges gyakorlatát és jogi feltételeit részletesen mutatta be. ${ }^{18}$

A bitcoin tömeges elterjedése óta élő a kérdés: vajon a szerződések teljes egészében kódolhatóak-e? Első ránézésre a hagyományos és az okosszerződések nem különböznek: mindkét esetben a felek először megegyeznek a szerződéses feltételekben, közös, egybehangzó akaratnyilatkozatot tesznek. Okosszerződések esetében a szöveges írásba foglalás helyett a felek egy kódba rögzítve tárolják a megegyezésüket, amelyet egy blokklánc-rendszer működtet. Vita esetén a felek akár újra is tárgyalhatják a megállapodásukat, vagy fordulhatnak jogvitájuk rendezése érdekében bírósághoz. Az eltérés főként a „szövegezésben” rejlik: az okosszerződések esetén nem a hagyományos jogi formulák és fordulatok kerülnek rögzítésre, hanem valamely programnyelv közvetítésének parancssorokká formálódik a megegyezés (például az Ethereum blokklánc Solidity-programnyelvét sokan használják okosszerződések rögzítésére) ${ }^{19}$. A szerződések ilyen módon automatizáltak lesznek, így nehezebb őket módosítani, illetve a megbeszélt teljesítéstől eltérni, mint egy hagyományos szerződés esetében, sőt, magának az automatizált teljesítési folyamatnak az egyoldalú megállítására sincsen módja a feleknek, csak

17 A kifejezés első használója Nick Szabó jogász-informatikus, aki 1994-ben megjelent cikkében írta le először a ma ismert és használt okosszerződések működésének alapelveit. Nick SzABo: Smart Contracts, 1994, http://www.fon.hum.uva.nl/rob/ Courses/InformationInSpeech/ CDROM/Literature/LOTwinterschool2006/szabo.best.vwh.net/smart.contracts.html (letöltés ideje: 2019. 10. 24.)

18 CzIróK Andrea, Nyerges Éva: Digitalizáció a munkajogban: Elektronikus munkaügyifolyamatok a „most” generációja számára, Munkajog, 2018/2, 33-38.

19 De FilipPI, Wright: Blockchain..., i. m., 74. 
ha ebben közösen állapodnak meg, és maga az eredeti kód is tartalmazott lehetőséget a módosításra. Az okosszerződések lehetővé teszik a harmadik felekkel való hatékony, dinamikus kapcsolatteremtést is (ilyenképpen lehetővé válik tőzsdei adatok, bankszámla-információk vagy akár időjárási adatok bekapcsolása a rendszerbe), így a szerződés képes külső hatásokra reagálni a felek jogviszonyán belül. ${ }^{20}$

\section{A digitális munkaszerződés létrehozása és müködése}

Az interneten bruttó $63 \mathrm{Ft}$-ért lehet ma munkaszerződésre vonatkozó mintát vásárolni, éppúgy, mint egy kiló kenyeret. ${ }^{21}$ A Munka törvénykönyvéről szóló 2012. évi I. tv. (Mt.) 45. §-a meghatározza a munkaszerződésben rögzítendő kötelező adattartalmat, amely értelmében a munkaszerződésben a feleknek meg kell állapodniuk a munkavállaló alapbérében és munkakörében, és adott esetben a munkaviszony tartamában és a munkavégzés helyében, bár a két utóbbi nélkül is érvényesen létrejön a munkaviszony [Mt. 45. § (2) és (3) bekezdések]. ${ }^{22}$ Csupán a fentiek alapján úgy tủnhet, hogy munkaszerződést kötni nem is olyan bonyolult dolog, már csak a kötelező tartalom kódolására van szükség az elektronikus megkötéshez ${ }^{23}$ és automatikus végrehajtáshoz. Ha ez így lenne, akkor a blokklánc-technológiát először ebben a szektorban vezették volna be, hiszen a munkaszerződés a világ egyik leggyakoribb szerződéstípusa.

A valóság azonban egy kicsit árnyaltabb. Az Mt. 46. § (1) bekezdés további tájékoztatási kötelezettséget ír elő a munkáltató számára: írásban kell tájékoztatni a munkavállalót a további fontos foglalkoztatási feltételekről, így a napi munkaidőről, az alapbéren túli munkabérről és egyéb juttatásokról, a munkabérről való elszámolás módjáról, a munkabérfizetés gyakoriságáról, a kifizetés napjáról, a munkakörbe tartozó feladatokról, a szabadság mértékéről, számítási módjáról és kiadásának, valamint a munkáltatóra és a munkavállalóra irányadó felmondási idő megállapításának szabályairól, továbbá arról, hogy a munkáltató kollektív szerződés hatálya alá tartozik-e, valamint a munkáltatói jogkör gyakorlójáról. ${ }^{24} \mathrm{Ha}$ a fenti pontokat megvizsgáljuk abból a szempontból, hogy

20 ld: https://blockchainhub.net/blockchain-oracles/ (letöltés ideje: 2020. 11. 03.)

21 Elérhetőség: https://www.alter.hu/munkaszerzodes-a-3-3-lapos-uj_58546 (letöltés ideje: 2020. 11.03.)

22 A munkaszerződés tartalmi elemeiről, a munkajogviszony létesítéséről részletesen lásd: BAnKó Zoltán: A munkajogviszony létesitése és kezdete = Kiss György (szerk.): Munkajog, Dialóg Campus, Budapest, 2020, 163-185., illetve Ferencz Jácint, Fodor T. Gábor, Kun Attila, MészÁros Katalin Éva: A munkaviszony létesitése, Wolters Kluwer, Budapest, 2016.

23 Ezzel párhuzamosan felvetődhetnek az írásba foglaláshoz kötött munkajogi jognyilatkozatok elektronikus dokumentumba foglalásával kapcsolatos dilemmák is (ld. a problémáról az Mt. vonatkozásában: PETRovics Zoltán: Az elektronikus dokumentum körüli dilemmák a munkajogban, HR \& Munkajog, 2016/10, 9-13.

24 A munkáltató tájékoztatási kötelezettségéről lásd bővebben: SiPKA Péter, ZACCARIA Márton Leó: Megújuló tájékoztatási kötelezettség a munkajogi viszonyokban és azokon túl, Munkajog, 2019/3, 1-8. és HUNGLER Sára: A munkáltatói kártéritési felelősség, mint a szociális integráció akadálya: Az autonóm szociális párbeszéd útján született keretmegállapodások átültetési nehézségei a magyar munkajogba, Gazdaság és Jog, 2020/3, 5-11. 
elektronikusan rögzíthetőek, illetőleg kódolhatóak-e, akkor egyértelműen igen a válasz. Ugyanakkor kérdés, hogy ha a munkavállalóval ezt egy kód formájában közöljük, az maradéktalanul kielégíti-e a tájékoztatási kötelezettséget? Álláspontom szerint semmiképpen, így a tájékoztatási kötelezettség bizonyos értelemben az okosszerződések egyik megoldandó problémája lehet, hiszen az adminisztrációs kötelezettségek megszegése felveti a munkáltató kártérítési felelősségét is. ${ }^{25} \mathrm{Ha}$ a gazdasági társaságok a blockchain (vagy DLT) rendszerekben rejlő tagadhatatlan előnyöket (automatizált szerződés-végrehajtás, visszamenőleg közel módosíthatatlan tartalom, tömeges alkalmazhatóság) a gazdasági élet több területén is sikerrel alkalmazzák, felmerül a kérdés, hogy a munkaviszonyok világában is megjeleníthetőek-e ezen előnyök. Könnyü elképzelni, hogy a munkaviszonyok egyes elemei automatizálhatóak lehetnének a fenti definíció és a már ismertetett szerződéskötési alapszabályok alapján: ha egy munkavállaló blokkol reggel és délután, a feladatait (elektronikusan) ellenőrizhetően teljesíti, akkor a hónap végén a munkabérét a rendszer automatikusan számfejt(het)i. A munkaidő-nyilvántartás meglévő problémái, vagy azok egy része a digitális nyomon követés révén orvosolhatóak lehetnek, a digitális nomádság mint munkavégzési forma több területen is teret hódíthatna, költséget megtakarítva a munkáltatónak. Sőt, felmerülhet egyes munkaviszonyok vagy még inkább feladatkörök esetében a munkaszerződések okosszerződéssé való alakításának kérdése is, amely viszont már munkajogi alapelvi kérdéseket vet fel. A nagyvállalatoknál tömegesen alkalmazott, hasonló munkakörben foglalkoztatott munkavállalók (például gyártósoron dolgozó összeszerelők, operátorok) esetében a gyakorlatban nagy hasonlóság fedezhető fel a munkaszerződések tartalmában: a munkaidő, a munkavégzés helye, a bérezés módja (sőt talán a munkabér is), a munkáltatói jogok gyakorlója, a felek jogai és kötelezettségei tekintetében mutatkozó összhang felveti a munkajogi ÁSZF-ek kérdését. Márpedig ha a munkajogban felfedezni vélnénk ilyen jellegű szerződéseket, azok könnyen átalakíthatóak lennének okosszerződésekké, és így a blockchain- (vagy DLT-) rendszerhez való csatlakoztatásuk csupán technikai kérdéssé egyszerüsödhetne.

\section{Irodalomjegyzék}

1. BAnkó Zoltán: A munkajogviszony létesitése és kezdete = Munkajog, szerk. Kiss György, Dialóg Campus, Budapest, 2020.

2. Czirók Andrea, Nyerges Éva: Digitalizáció a munkajogban: Elektronikus munkaügyifolyamatok a „most” generációja számára, Munkajog, 2018/2.

3. De FilipPI, Primavera, Wright, Aaron: Blockchain and the Law. The Rule of Code, Harvard University Press, London, 2018.

4. Ferencz Jácint, Fodor T. Gábor, Kun Attila, MÉszÁros Katalin Éva: A munkaviszony létesitése, Wolters Kluwer, Budapest, 2016.

25 SipKa Péter: A munkáltatói kárfelelősség alakulása a bírói gyakorlat tükrében, HVG-ORAC, Budapest, 2015, 155. 


\section{ERDÉLYI JOGÉLET}

5. G. KaRÁCSONy Gergely: A mesterséges intelligenciák szabályozásának közjogi kérdései=Agazdasági jogalkotás aktuális kérdései, szerk. Glavanits Judit, Dialóg Campus Kiadó, Budapest, 2019.

6. G. KarÁcsony Gergely: Okoseszközök - okos jog?, Ludovika Egyetemi Kiadó, Budapest, 2020.

7. Glavanits Judit, KIRÁly Péter Bálint: A blockchain-technológia alkalmazásánakjogi előkérdései: a fogalmi keretek pontositásának szükségessége, Jog - Állam - Politika, 2018/3.

8. Glavanits Judit: Sustainable Public Spending Through Blockchain, European Journal of Sustainable Developement, 2020/4.

9. Hileman, Garrick, Rauch, Michel: Global Cryptocurrency Benchmarking Study. Cambridge Center for Alternative Finance, University of Cambridge, Judge Business School, 2017.

10. Hungler Sára: A munkáltatói kártéritési felelősség, mint a szociális integráció akadálya: Az autonóm szociális párbeszéd útján született keretmegállapodások átültetési nehézségei a magyar munkajogba, Gazdaság és Jog, 2020/3.

11. Petrovics Zoltán: Az elektronikus dokumentum körüli dilemmák a munkajogban, HR \& Munkajog, 2016/10.

12. PfefFer Zsolt: A fizetésre használható virtuális eszközök, Kodifikáció és Közigazgatás, 2017.

13. Raskin, Max: The Law and the Legality of Smart Contracts, Georgetown Law Technology Review, Vol. 1:2.

14. SiPKA Péter: A munkáltatói kárfelelősség alakulása a bírói gyakorlat tükrében, HVG-ORAC Lapés Könyvkiadó Kft., Budapest, 2015.

15. SiPKA Péter, ZACCARIA Márton Leó: Megújuló tájékoztatási kötelezettség a munkajogi viszonyokban és azokon túl, Munkajog, 2019/3.

16. TRENYISÁN Máté: A munkáltató kártéritési felelőssége a magánmunkajogban (kismonográfia), Nemzeti Közszolgálati Egyetem, Budapest, 2018.

17. Wright, Aaron, De FilipPI, Primavera: Decentralized Blockchain Technology and the Rise of Lex Cryptographia (March 10, 2015), SSRN: https://ssrn.com/abstract=2580664 or http://dx.doi. org/10.2139/ssrn.2580664

18. Z. Karvalics László, Nagy Gábor Dániel: Prokrusztész nélküli világ? Blokklánc és társadalmi makroevolúció, Információs Társadalom, XVII. évf., 2017/3.

\section{Egyéb hivatkozások}

1. http://www.mnb.hu/sajtoszoba/sajtokozlemenyek/2014-evi-sajtokozlemenyek/az-mnb-kockazatosnak-tartja-a-fizetesre-hasznalhato-virtualis-eszkozoket-peldaul-a-bitcoint

2. https://blockchainhub.net/blockchain-oracles/

3. https://www.alter.hu/munkaszerzodes-a-3-3-lapos-uj_58546

4. https://www.bitcoinbazis.hu/okosszerzodes-ugyved-vagy-hacker/

5. https://www.inc.com/eric-mack/meet-publicly-traded-company-paying-employees-in-bitcoin.html

6. Szabo Nick: Smart Contracts, 1994, http://www.fon.hum.uva.nl/rob/ Courses/InformationInSpeech/CDROM/Literature/LOTwinterschool2006/szabo.best.vwh.net/smart.contracts. html

7. Matthiews, Kayla: Why Employers Can’t Pay You in Cryptocurrency. https://cointelegraph. com/news/why-employers-cant-pay-you-in-cryptocurrency 